\title{
Studies on the Behaviour of Pseudomonas fluorescens Biofilms after Ortho-phthalaldehyde Treatment
}

\author{
MANUEL SIMÕES ${ }^{a}$, HELENA CARVALHO $^{a}$, MARIA OLIVIA PEREIRA $^{a}$ and MARIA JOÃO VIEIRA ${ }^{\mathrm{a}, *}$ \\ Centro de Engenharia Biológica-IBQF, Universidade do Minho, 4710-057, Braga, Portugal
}

(Received 18 June 2002; in final form 11 October 2002)

A relatively novel biocide, ortho-phthalaldehyde (OPA), was tested to control biofilms formed by Pseudomonas fluorescens on stainless steel surfaces. The toxic action of OPA was assessed in terms of inactivation and removal of the biofilm by means of, respectively, the determination of the respiratory activity and the variation in the dry weight of the biofilms. For comparison, the activity of OPA against suspended bacteria was also evaluated. The results showed that higher concentrations of OPA and longer exposure times are needed to inactivate $P$. fluorescens biofilms than planktonic populations, thus denoting that sessile bacteria have a reduced susceptibility to OPA. This appears to be associated with the reaction with the proteins of the matrix, as demonstrated by the reduction of the antimicrobial action of OPA in the presence of a protein (bovine serum albumin). The application of OPA appeared to cause little effect in the removal of biofilms from the metal slides since the mass of biofilm that remained on the surfaces, after biocide treatment, was within the same range as those observed in the control tests. These results suggest that, with OPA application, biofilms can be inactivated but stay attached to the surfaces, decreasing thereby the success of the chemical treatment.

Keywords: ortho-phthalaldehyde; disinfection; biofilm removal; Pseudomonas fluorescens

\section{INTRODUCTION}

The development of biofilms on wet surfaces is a natural phenomenon in various places in nature as well as on industrial equipment and on medical devices, causing several drawbacks (Flemming, 1997; Griebe \& Flemming, 1998). The main strategy of biofilm control is the use of chemical biocides (i.e. disinfectants) to kill the attached microorganisms and/or remove them from the surface. In industrial systems, it is of primary importance that both the inactivation of the microorganisms and the removal of biofilm from the surfaces are achieved. When disinfection without removal takes place, the inactivated biofilm may provide an ideal environment for further adhesion and growth. Moreover, if disinfection is not fully effective, regrowth of the biofilm may occur.

Ortho-phthalaldehyde (OPA) is a new type of disinfectant that is claimed to have a potent bactericidal and sporicidal activity (McDonnell \& Russell, 1999; Cabrera-Martinez et al., 2002) and has been suggested as a possible alternative to glutaraldehyde (GTA) for high level disinfection (Alfa \& Sitter, 1994; Walsh et al., 1999a; 2001; Fraud et al., 2001). These studies may indicate that OPA may also be used for biofilm control in industrial systems. So far, there are no reports on the effects of OPA on biofilms. Since biofilms are very complex structures, where bacteria are embedded in a complex matrix of polymers, the evaluation of the biocide against the sessile bacteria must be carried out in this special type of environment. Albeit the recommended procedure to evaluate biocide efficacy is based on tests on suspended cells (European Standard EN 1276) it may give misleading results. There are several reasons which may account for the differences between tests with suspended bacteria and with biofilms, viz.: the exopolymeric matrix produced by the microorganisms protects them from the action of the harmful agent (Christensen \& Characklis, 1990); the matrix may have degradative enzymes that inactivate the biocide (Heinzel, 1998); reaction of the biocide with community components (Pereira \& Vieira, 2001); the exopolysaccharide matrix is a charged matrix, being responsible for binding anti-

*Corresponding author; fax: 00351253 678986; e-mail: mjv@deb.uminho.pt 
microbial agents before they reach the target cell (Costerton, 1985) and the physiological state of the sessile cells is different from that in the planktonic phase (Morton et al., 1998).

The mechanisms of resistance to biocides shown by microorganisms growing within a biofilm can be considered as being of two types: intrinsic resistance and acquired resistance (Russel, 1995). Intrinsic resistance is a natural controlled property or physiological adaptation of the microorganism. Acquired resistance results from genetic changes in a bacterial cell and arises either by mutation or by the acquisition of genetic material (plamids, transposons) from another cell.

OPA is an aromatic compound with two aldehyde groups. Its antimicrobial action is not well known, although some authors (Walsh et al., 1999b) suggested an action similar to that of GTA, i.e. the strong reaction of OPA with primary amines and the consequence stabilization of the outer membrane and cell wall of the microorganisms may explain its lethal action.

This work reports the evaluation of the performance of ortho-phthalaldehyde against both suspended bacterial cultures and biofilms formed by Pseudomonas fluorescens, a very common strain in industrial environments. The experimental tests were performed using a range of concentrations of OPA and exposure times against biofilms formed over $6 \mathrm{~d}$. Tests were also performed with $P$. fluorescens suspensions for comparison since disinfectants with high activity in suspension tests are not necessarily as active against biofilms as previously referred.

\section{MATERIAL AND METHODS}

\section{Microorganism}

The Gram-negative aerobic bacterium Pseudomonas fluorescens ATCC 13525 was used throughout this study.

\section{Biocide}

The biocide used in this study was ortho-phthalaldehyde obtained as a powder from Sigma (P-1378). Before each experiment, stock solutions of 1 and $2 \mathrm{~g}^{-1}$ were prepared in sterile distilled water and stored at room temperature. The biocide solutions were diluted to the required concentration with sterile distilled water.

\section{Experiments with Suspended Microorganisms}

\section{Microorganism growth}

A continuous pure culture of $P$. fluorescens was produced as described elsewhere (Pereira et al.,
1998). The bacterial culture was grown at $27 \pm 1^{\circ} \mathrm{C}$ in a 31 glass fermenter, suitably aerated and magnetically agitated. The fermenter was continuously fed with $10 \mathrm{ml} \mathrm{h}^{-1}$ of a sterile nutrient solution composed of $5 \mathrm{~g}$ glucose $1^{-1}, 2.5 \mathrm{~g}$ peptone $1^{-1}$ and $1.25 \mathrm{~g}$ yeast extract $\mathrm{l}^{-1}$, in phosphate buffer at $\mathrm{pH} 7$ $\left(0.2 \mathrm{M} \mathrm{Na}_{2} \mathrm{HPO}_{4}\right.$ and $\left.0.2 \mathrm{M} \mathrm{NaH}_{2} \mathrm{PO}_{4}\right)$.

\section{Biocide Treatment}

Periodically, a suitable amount of $P$. fluorescens culture was removed from the fermenter, centrifuged $(3777 \times \mathrm{g}, 10 \mathrm{~min})$ and washed three times with saline solution $(\mathrm{NaCl}, 0.85 \%)$. The pellets were resuspended in phosphate buffer $\mathrm{pH} 7$ in order to obtain a final suspension with an optical density of $0.8(\lambda=640 \mathrm{~nm})$ that corresponds to $\sim 8 \times 10^{8} \mathrm{CFU} \mathrm{ml}^{-1}$ (Stelmack et al., 1999). The bacterial culture was then divided into several sterilized glass flasks, exposed to different OPA concentrations $\left(5,10,15,20\right.$ and $\left.50 \mathrm{mg} \mathrm{l}^{-1}\right)$ and then put in an orbital shaker (120 rpm). The effect of biocide was assessed over time (5, 60 and $180 \mathrm{~min}$ ) by means of bacterial respiratory activity through oxygen consumption in a respiration chamber. The mass of bacteria present in each glass flask was estimated by the determination of the total volatile solids (TVS) of the bacterial cultures, according to the APHA Standard Methods (1989).

To investigate the influence of the proteins on the biocide efficacy, the procedure described above was followed, but with the addition of different concentrations of bovine serum albumin (BSA) (Merck 12018), namely $0.72,0.36$ and $0.18 \%$, to the bacterial suspensions.

\section{Experiments with Biofilms}

\section{Biofilm set-up}

Biofilms were grown on ASI 316 stainless steel slides $(2.5 \times 2.5 \mathrm{~cm}$ and $1 \mathrm{~mm}$ thick) that were hung within a well stirred reactor containing a batch bacterial culture. The operating conditions of the reactor system have been described previously (Pereira \& Vieira, 2001). The reactor was continuous fed with a sterile medium consisting of $50 \mathrm{mg}$ glucose $1^{-1}$, $25 \mathrm{mg}$ peptone $1^{-1}$ and $12.5 \mathrm{mg}$ yeast extract $1^{-1}$, in phosphate buffer $\mathrm{pH} 7$. The biofilm was allowed to grow for $6 \mathrm{~d}$ (the time need to reach the steady state) and was sampled prior to the start of the OPA treatment.

\section{Biocide treatment}

The slides covered with biofilms were carefully transferred to closed vases containing the OPA solutions $\left(10,25,50\right.$ and $\left.100 \mathrm{mg} \mathrm{l}^{-1}\right)$. At known time intervals (5, 60 and $180 \mathrm{~min}$ of biocide contact time), 
the metal slides plus biofilm were carefully removed from the biocide-containing flask and immediately analysed for the evaluation of OPA action.

The biofilm that covered the metal slides was completely scrapped from the metal slides into $10 \mathrm{ml}$ of phosphate buffer $\mathrm{pH} 7$ and vigorously homogenized in a vortex. The homogenized suspensions of biofilms were used to assess the bacterial activity of the biofilm. The biofilms suspensions that were not treated with OPA were also analysed for total protein and polysaccharide.

\section{Analytical Methods}

The proteins were determined using the Lowry modified method (SIGMA-Protein Assay Kit No P5656) and the polysaccharides by the phenolsulphuric acid method of Dubois et al. (1956). The dry biofilm mass accumulated on the slides was assessed by the determination of the total volatile solids (TVS) of the homogenized biofilm solutions, according to the APHA Standard Methods (1989), and expressed in $\mathrm{g}$ of biofilm per $\mathrm{cm}^{2}$ of surface area of the metal slide $\left(\mathrm{g}_{\text {biofilm }} \mathrm{cm}^{-2}\right.$ ).

\section{Respiratory Activity Assessment}

The respiratory activity of the several samples was evaluated by measuring oxygen uptake rates in a biological oxygen monitor (BOM) in short-term assays. The assays were performed in a Yellow Springs Instruments BOM (Model 53), and the procedure used was described elsewhere (Pereira et al., 2002). Before each respirometric assay, the samples were carefully washed three times with saline solution $(\mathrm{NaCl}, 0.85 \%)$ in order to guarantee the absence of carbon sources and others external energy sources for the bacteria, resuspended in $10 \mathrm{ml}$ of phosphate buffer $\mathrm{pH} 7$ and placed in the temperature-controlled vessel of the BOM $\left(T=27 \pm 1^{\circ} \mathrm{C}\right)$. With this careful washing procedure, the residual OPA concentration in each bacterial culture or biofilm sample was also reduced to a level significantly low so as not to cause any further cell damage. Therefore, it is acceptable to assume that the toxic effect of OPA was practically inactivated.

The temperature-controlled vessel of the BOM contains a dissolved oxygen (DO) probe connected to a DO meter. Once inside the vessel, the samples were aerated for $30 \mathrm{~min}$ to ensure oxygen saturation. The vessel was closed and the decrease in the oxygen concentration was monitored over time. The initial linear decrease observed corresponds to the endogenous respiration rate. To determine the oxygen uptake due to substrate oxidation, a small volume $(50 \mu \mathrm{l})$ of a glucose solution $\left(100 \mathrm{mg} \mathrm{l}^{-1}\right)$ was injected within each vessel. The slope of the initial linear decrease in the DO concentration, after glucose injection, corresponds to the total respiration rate. The difference between the two respiration rates gives the oxygen uptake rate due to glucose oxidation.

All the respirometric tests were carried out at least three times.

\section{Scanning Electron Microscope (SEM) Observations}

During the experiments, several stainless steel slides covered with biofilms were observed by SEM. The SEM inspection always comprised the observation of at least 10 fields of each biofilm-covered metal slide. Prior to SEM observations, the biofilm samples were gradually dehydrated in an absolute ethanol series to $100 \%$ (15 min each in 10, 25, 40, 50, 70, 80, 90 and $100 \% \mathrm{v} / \mathrm{v}$ ), and dried in a desiccator for $3 \mathrm{~d}$. The samples were sputter-coated with gold and examined with a Leica S360 scanning electron microscope at $10-15 \mathrm{kV}$. The slides were not fixed because fixation procedures involve the use of chemicals that tend to react with some of the components of the biological matrix, as documented by Azeredo et al. (1999), hence modifying the real biofilm structure.

SEM observations were documented through the acquisition of representative microphotographs.

\section{Epifluorescence Microscopy}

The effect of OPA on the biofilm-covered metal slides was also investigated using epifluorescence microscopy (Zeiss Microscope) fitted with fluorescence illumination (Filter Zeiss No 09, BP excitation between $450-490 \mathrm{~nm}$ ) with acridine orange (Merck 15931.0025) as the fluorescent dye. Acridine orange (AO) binds to nucleic acids with the RNA-AO complex fluorescing orange-red while the DNA-AO complex fluoresces green (Bitton et al., 1993). During the experiments, some biofilm-covered metal slides were removed from the vessels, and washed threetimes gently in ultra-pure sterile water to remove the reversibly attached biofilm, and stained with $0.003 \%$ $(\mathrm{w} / \mathrm{v})$ acridine orange prepared in acetic acid solution for $5 \mathrm{~min}$ at room temperature in the dark. Prior to the observation, the slides were gently washed with sterile distilled water to remove excess stain.

\section{RESULTS AND DISCUSSION}

The effects of OPA on the P. fluorescens biofilms were investigated by assessing the respiratory activity of the bacterial cells and the variation in the mass of the biofilms during the disinfection period.

The results revealed that OPA reduced the biofilm activity for all the biocide concentrations studied (Figure 1). Nevertheless, the extent of respiratory 


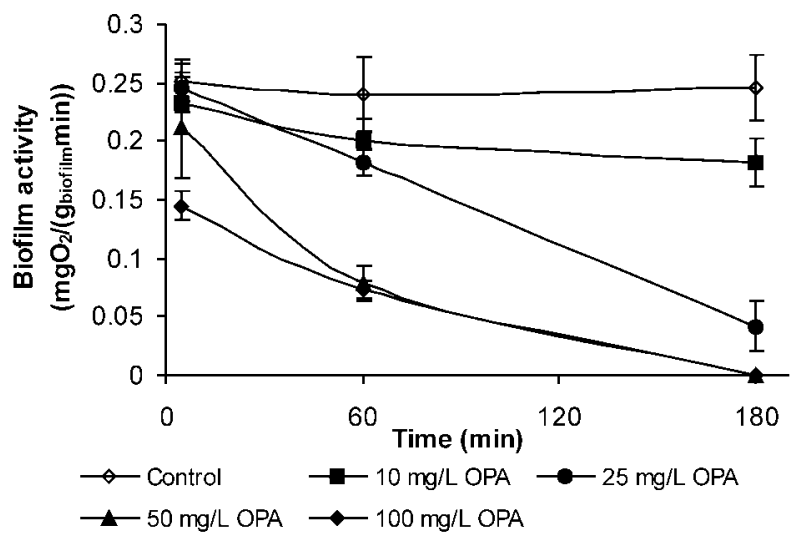

FIGURE 1 Bacterial activity of the $P$. fluorescens biofilms when treated with several concentrations of OPA. Bars $=\mathrm{SD}$ of the mean.

activity reduction was only significant for higher OPA concentrations and for longer exposure times. The total inactivation of the biofilm was only achieved with 50 and $100 \mathrm{mg}^{-1}$ of OPA after $3 \mathrm{~h}$ exposure to the biocide. Short exposure periods, such as $5 \mathrm{~min}$, seem not to be sufficient for OPA to carry out its antimicrobial action, since a significant biofilm activity decrease was only detected with the higher OPA concentrations. These remarks point to OPA as a disinfectant dependent on exposure time.

The effect of OPA on biomass reduction can be observed in Figure 2. The results demonstrate that OPA seems to have poor removal action since the amount of biofilm mass that remained on the steel surfaces after biocide treatment was within the same range as those measured in the control assay. This is not surprising since OPA, as others aldehydes (Workman \& Day, 1984; Flemming \& Schaule, 1996), was originally used as tissue fixative. The biomass of the biofilm did not significantly decrease after OPA treatment because, most likely, biofilm was being "fixed" to some extent to the metal slide. Only for OPA concentrations $>10 \mathrm{mg} \mathrm{l}^{-1}$ was it possible to notice some biofilm removal, this removal being, however, quite independent of the increase in OPA concentration. Apparently, for the higher OPA concentrations (50 and $100 \mathrm{mg}^{-1}$ ), the removal was dependent on the exposure time since the reduction in biofilm mass increased with time. Nevertheless, these reduction values are not statistically relevant, especially when the standard deviation values are taken into account.

In this study, the evidence of bacterial biofilm on the metal slides before the treatment and the possible damage resulting from OPA treatment were inspected by SEM. Figure 3 displays some microphotographs representative of the several fields observed in each biofilm-covered metal slide. As can be seen in this figure, the extent of biofilm growth on the metal slides was considerable but not uniform. On the same stainless steel slide it was possible to observe areas

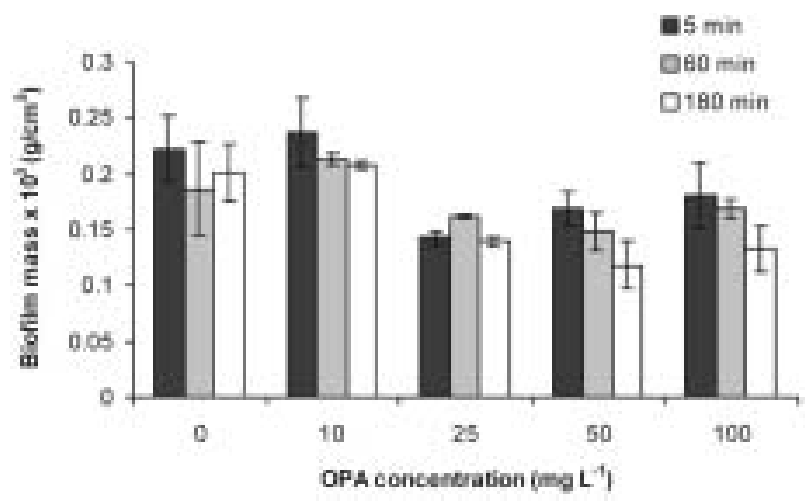

FIGURE 2 Remained biofilm mass after application of OPA. Mean values \pm SD.

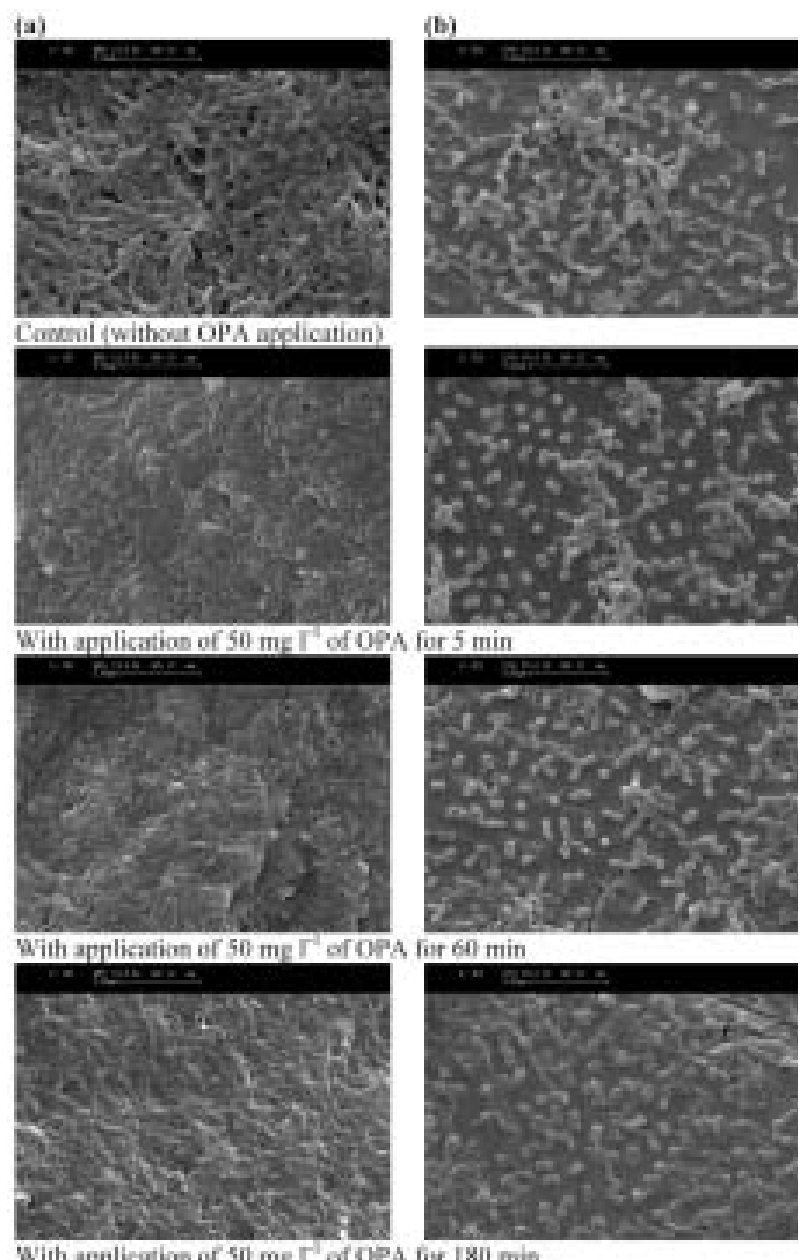

With application of $50 \mathrm{mg} \mathrm{r}^{-1}$ of OPA for $180 \mathrm{~min}$

FIGURE 3 SEM photomicrographs of a $6 \mathrm{~d}$ old $P$. fluorescens biofilm formed on stainless steel slides, without biocide application and after treatment with $50 \mathrm{mg} \mathrm{l}^{-1}$ OPA. (a) area totally covered with biofilm; (b) area with scattered cells. Bars $=5 \mu \mathrm{m}$.

totally covered by biofilm (Figure 3a) and zones with only scattered adhered bacteria (Figure $3 b$ ). The SEM microphotographs also showed that the OPA attack, for all the exposure times tested, seemed not to cause any noticeable damage to the structure and integrity of the bacterial biofilms. 
The results presented so far underscore the fact that biofilm inactivation and biofilm removal are distinct processes. In this study, OPA caused a significant reduction in biofilm activity conversely to biofilm removal. Consequently, it is possible to conclude that OPA is more effective in disinfecting biofilms than in promoting their removal from the surfaces. This OPA characteristic supports the need for implementing, in conjunction with this biocide, another strategy of biofilm control in order to promote the disruption of the EPS matrix, followed by the removal of the biofilm. In many systems where problematic biofilm fouling occurs, the main objective is to have clean surfaces rather than an inactive biofilm attached to the surfaces (Chen \& Stewart, 2000). For instance, in the medical area, where OPA is, up to this time, employed, full cleaning of medical devices and other surfaces is often required before treatment with biocides in order to remove organic substances that may interfere with biocide action.

For comparative purposes, the action of OPA against suspended cultures of $P$. fluorescens was also assessed. As can be seen in Figure 4, the application of OPA to the bacterial suspensions caused a decrease in the bacterial respiratory activity, for all the concentrations tested. However, the decrease in bacterial activity was gradually enhanced by increasing the OPA concentration.

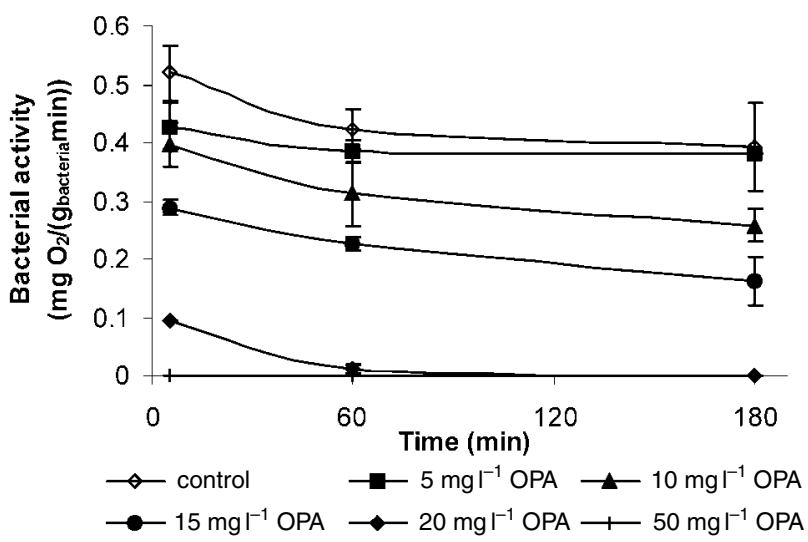

FIGURE 4 Bacterial activity of the suspended cultures of $P$. fluorescens without biocide application and after treatment with several concentrations of OPA. Mean values \pm SD.
As can be seen in Figures 1 and 4, the OPA concentration needed to cause the total inactivation of the suspended bacterial cultures was lower than the biocide amount required for biofilm inactivation. To make easier and more helpful the comparison of the results presented in these figures, the percentage decreases obtained due to the application of different concentrations of OPA to both biofilms and suspended cultures were calculated and are presented in Table I. Conversely to what seemed to happen with biofilms, the action of OPA against the planktonic cultures appeared to be more immediate, i.e. its toxic action did not significantly increase with increasing biocide contact time. These data also emphasize that $P$. fluorescens, when grown in a biofilm, was less sensitive to the aggressive action of OPA.

Several suggestions have been made to explain biofilm resistance to biocides (Morton et al., 1998). In this study, the reduced bacterial susceptibility to OPA when the cells were entrapped in a biofilm may also be explained by the polymeric matrix that biofilms exhibit (Heinzel, 1998). The SEM microphotographs depicted in Figure 3 revealed that the $P$. fluorescens biofilms had a stronger exopolymer (EPS) matrix, which seemed not to be disrupted with the application of OPA. Several biofilm samples were also inspected by epifluorescence microscopy with the aim of identifying the exopolymer layer after the staining procedure with acridine orange $(\mathrm{AO})$, since this dye reacts with polymeric matrix. It is known that DNA is one of the components of Pseudomonas biofilm matrixes (Palmgren \& Nielsen, 1996; Jahn et al., 1999) and AO binds to nucleic acids with the RNA-AO complex fluorescing orange-red while the DNA-AO complex fluoresces green (Bitton et al., 1993). Therefore, it is not surprising to observe a polymeric layer fluorescing green, since $\mathrm{AO}$ binds to the DNA of the matrix. The epifluorescence microphotographs of the biofilms (Figure 5) reinforce the fact that the polymeric layer was not disrupted, since it was possible to observe that the EPS matrix (stained green) that involves the bacteria remained unchanged after attack with $50 \mathrm{mg} \mathrm{l}^{-1}$ of the disinfectant for $1 \mathrm{~h}$. This EPS matrix may constitute a penetration barrier to the diffusional entrance of OPA conferring, in this way, on the bacteria of the

TABLE I Comparison of the reduction in the respiratory activity of the P. fluorescens biofilms and the suspended bacterial cultures after treatment with several OPA concentrations, as a function of time. The percentage reduction was calculated on the basis of the control assays, that is on the respiratory activity of the bacterial biofilms and suspended bacterial cultures, in the absence of OPA

\begin{tabular}{|c|c|c|c|c|c|c|c|c|c|}
\hline \multirow[b]{3}{*}{$\begin{array}{l}\text { OPA contact } \\
\text { time (min) }\end{array}$} & \multicolumn{9}{|c|}{ Reduction in respiratory activity (\%) } \\
\hline & \multicolumn{4}{|c|}{ Bacterial biofilms } & \multicolumn{5}{|c|}{ Suspended bacterial cultures } \\
\hline & $\begin{array}{c}10 \mathrm{mg}^{-1} \\
\text { OPA }\end{array}$ & $\begin{array}{c}25 \mathrm{mg}^{-1} \\
\text { OPA }\end{array}$ & $\begin{array}{c}50 \mathrm{mg} \mathrm{l}^{-1} \\
\text { OPA }\end{array}$ & $\begin{array}{c}100 \mathrm{mg} \mathrm{l}^{-1} \\
\text { OPA }\end{array}$ & $\begin{array}{c}5 \mathrm{mg} \mathrm{l}^{-1} \\
\text { OPA }\end{array}$ & $\begin{array}{c}10 \mathrm{mg}^{-1} \\
\text { OPA }\end{array}$ & $\begin{array}{c}15 \mathrm{mg} \mathrm{l}^{-1} \\
\text { OPA }\end{array}$ & $\begin{array}{c}20 \mathrm{mg}^{-1} \\
\text { OPA }\end{array}$ & $\begin{array}{c}50 \mathrm{mg} \mathrm{l}^{-1} \\
\text { OPA }\end{array}$ \\
\hline 5 & 7.9 & 2.4 & 15.9 & 42.5 & 17.7 & 23.7 & 44.5 & 81.9 & 100 \\
\hline 60 & 16.7 & 24.2 & 67.1 & 70.7 & 9.2 & 26.3 & 46.9 & 97.4 & 100 \\
\hline 180 & 26.0 & 82.9 & 100 & 100 & 2.7 & 34.1 & 58.7 & 100 & 100 \\
\hline
\end{tabular}


biofilm partial protection from the bactericidal agent, as suggested by Cloete et al. (1998). Heinzel (1998) also states that the formation of an EPS matrix by the bacteria growing within biofilms is the main mechanism of intrinsic resistance to antibacterial agents.

Nevertheless, the barrier protection provided by the biofilm EPS matrix may not be the sole explanation for the increased OPA resistance of biofilmresident bacteria. Besides the physical hindrance of biocide diffusion, the protective property of the EPS matrix could also be due to others factors such as absorption (Nichols, 1994) or chemical reaction (Morton et al., 1998) between the aggressive agent and the biofilm surface.

Previous works (Jahn et al., 1999; Pereira \& Vieira, 2001) have shown that the EPS matrix of biofilms developed by the genus Pseudomonas was composed of proteins in addition to the polysaccharide content. Pereira and Vieira (2001) also reported that the EPS matrix of $P$. fluorescens biofilms had a content of total proteins higher than the polysaccharide fraction. Thus, in the case under study, the higher protein content displayed by the bacterial biofilms, when compared with the polysaccharide fraction (Table II) comprises not solely that of the bacteria but also includes the proteins of the polymeric matrix. Simons et al. (2000) reported that OPA, due to its lipophilic aromatic nature, interacts strongly with microorganisms and also with amino acids and proteins. In the light of these remarks, it is suggested that the low efficacy of OPA when applied against biofilms may also be due to the reaction of OPA with the proteins of the polymeric matrix.

The data displayed in Figure 6 corroborate this suggestion, since it revealed that the antimicrobial action of this disinfectant was severely affected by the

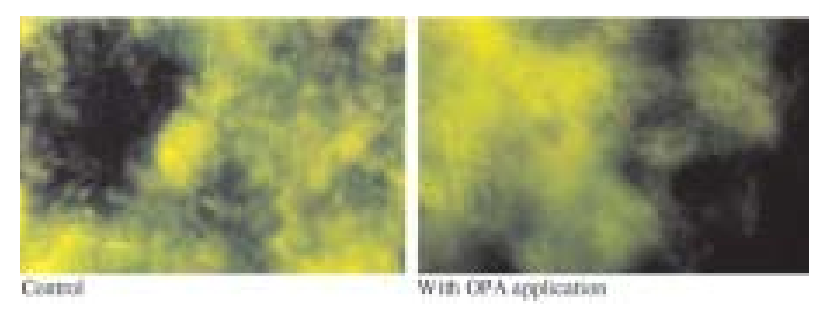

FIGURE 5 Epifluorescence photomicrographs of a $6 \mathrm{~d}$ old $P$. fluorescens biofilm formed on stainless steel slides, without biocide application (control) and after $60 \mathrm{~min}$ treatment with $50 \mathrm{mg} \mathrm{l}^{-1}$ OPA. $\times 100$ magnification; green colour = polymeric matrix; black colour $=$ background .

TABLE II Characteristics of P. fluorescens biofilms

\begin{tabular}{ccc}
\hline $\begin{array}{c}\text { Biofilm mass } \\
\left(\mathrm{g}_{\text {biofilm }} / \mathrm{cm}^{2}\right)\end{array}$ & $\begin{array}{c}\text { Total protein } \\
\left(\mathrm{mg}_{\text {protein }} / \mathrm{g}_{\text {biofilm }}\right)\end{array}$ & $\begin{array}{c}\text { Total polysaccharide } \\
\left(\mathrm{mg}_{\text {polysaccharide }} / \mathrm{g}_{\text {biofilm }}\right)\end{array}$ \\
\hline $0.203( \pm 0.018)$ & $217,7( \pm 22.5)$ & $63.3( \pm 2.8)$ \\
\hline
\end{tabular}

Mean values \pm SD presence of a protein (BSA). As can be seen in Figure 6, the lethal action of $50 \mathrm{mg}^{-1}$ of OPA against the bacterial cells became significantly less intense in the presence of BSA. The reduction in bacterial activity observed after exposure to $50 \mathrm{mg} \mathrm{l}^{-1}$ OPA for $1 \mathrm{~h}$ ( $\sim 99.3 \%)$ decreased substantially when the protein was added to the suspended cultures (23.8, 24.5 and $34.2 \%$, respectively for $0.72,0.36$ and $0.18 \%$ BSA).

The interaction between OPA and the proteins of the EPS matrix of the P. fluorescens biofilms confers on this bacterium an increased tolerance to OPA that can also be characterized as intrinsic resistance.

\section{CONCLUSIONS}

This study showed that, when entrapped in a biofilm, $P$. fluoresens presents a reduced susceptibility to OPA. This fact probably results from the interaction of the biocide with the proteins of the polymeric matrix, since it was demonstrated that the antimicrobial action of OPA is reduced in the presence of BSA. The nature of the interaction, i.e. chemical reaction or physical binding, is not yet clear, so further studies are needed.

It can also be concluded that the action of OPA, when used to control biofilms formed by P. fluorescens, is essentially that of a disinfectant since this chemical agent causes a substantial reduction in biofilm activity but not biofilm removal. Nevertheless, the biocidal efficacy of OPA was improved by increasing the exposure time and the concentration. The low efficiency of OPA in removing biofilm from the metal slides could be due to the fixation of the biomass to the metal surfaces, since OPA was originally used as a tissue fixative. These findings highlight the fact that, besides the chemical treatment with disinfectants, biofilm control strategies should always comprise practical cleaning for biofilm removal.

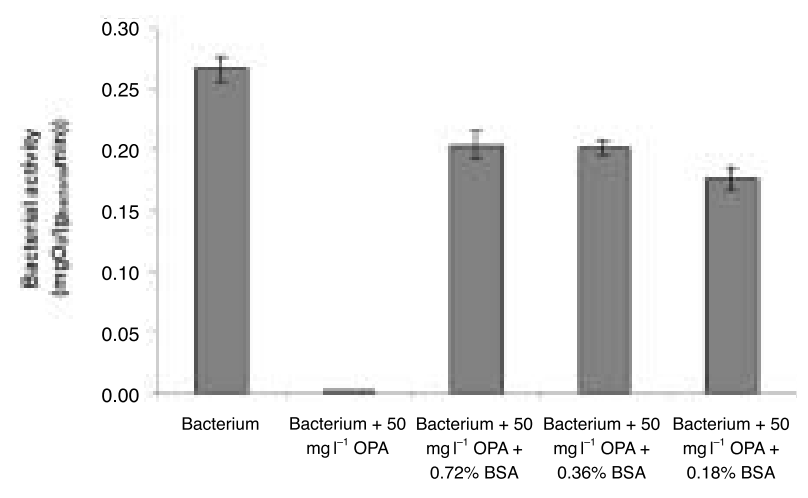

FIGURE 6 Bacterial activity of the suspended cultures of $P$. fluorescens without biocide application and after treatment with $50 \mathrm{mg} \mathrm{l}^{-1}$ OPA, with and without BSA addition. Mean values \pm SD. 


\section{Acknowledgements}

The authors acknowledge the financial support provided by IBQF and FCT, Portuguese Foundation for Science and Technology, through the project POCTT/1999/BIO/35683 and PhD grant awarded to Manuel Simões.

\section{References}

Alfa M J, Sitter D L (1994) In-hospital evaluation of orthophthaldehyde as a high level disinfection for flexible endoscopes. I Hosp Infect 26: 15-26

APHA, AWWA, WPCF (1989) Clesceri L S, Greenberg A E, Trussel R R (eds) Standard Methods for the Examination of Water and Wastewater, $17^{\text {th }}$ Edition. American Public Health Association, Washington DC, USA

Azeredo J A, Lazarova V, Oliveira R (1999) Methods to extract the exopolymeric matrix from biofilms: a comparative study. Water Sci Technol 39: 243-250

Bitton G, Koopman B, Keumhee J, Voiland G, Kotob M (1993) Modification of the standard epifluorescence microscopic method for total bacterial counts in environmental samples. Water Res 27: 1109-1112

Cabrera-Martinez R-M, Setlow B, Setlow P (2002) Studies on the mechanism of the sporicidal action of ortho-phthalaldehyde. $J$ Appl Microbiol 92: 675-680

Chen X, Stewart P S (2000) Biofilm removal caused by chemical treatments. Water Res 34: 4229-4233

Christensen B E, Characklis W G (1990) Physical and chemical properties of biofilms. In: Characklis W G, Marshall K C (eds) Biofilms. John Wiley and Sons Inc, New York, pp 93-130

Cloete T E, Jacobs L, Brözel V S (1998) The chemical control of biofouling in industrial water systems. Biodegradation 9: 23-37

Costerton J W (1985) The role of bacterial exopolysaccharides in nature and disease. Developments in Industrial Microbiology 26: 249-261

Dubois M, Gilles K A, Hamilton J K, Rebers A, Smith F (1956) Colorimetric method for determination of sugars and related substances. Anal Chem 28: 350-356

European Standard Chemical disinfectants and antiseptics (1997) EN 1276: Quantitative suspension test for the evaluation of bactericidal activity of chemical disinfectants and antiseptics used in food, industrial, domestic, and institutional areas. BSI, London

Flemming H-C (1997) Reverse osmosis membrane biofouling. Exp Therm Fluid Sci 14: 382-391

Flemming H-C, Schaule G (1996) Measures against biofouling. In: Heitz E, Flemming H-C, Sand W (eds) Microbially Influenced Corrosion of Materials. Springer-Verlag, Heidelberg, pp 121-139

Fraud S, Maillard J-Y, Russel A D (2001) Comparison of the mycobactericidal activity of ortho-phthalaldehyde, glutaraldehyde and other dialdehydes by a quantitative suspension test. J Hosp Inf 48: 214-221
Griebe T, Flemming H-C (1998) Biocide-free antifouling strategy to protect RO membranes from biofouling. Desalination 118: 153156

Heinzel M (1998) Phenomena of biocide resistance in microorganisms. Int Biodeterior Biodegr 41: 225-234

Jahn A, Griebe T, Nielsen P H (1999) Composition of Pseudomonas putida biofilms: accumulation of protein in the biofilm matrix. Biofouling 14: 49-57

McDonnell G, Russel A D (1999) Antiseptics and disinfectants: activity, action and resistance. Clin Microbiol Rev 12: 147-179

Morton L H G, Greenway D L A, Gaylarde C C, Surman S B (1998) Consideration of some implications of the resistance of biofilms to biocides. Int Biodeterior Biodegr 41: 247-259

Nichols W W (1994) Biofilm permeability to antibacterial agents. In: Wimpenny J, Nichols W W, Stickler D, Lappin-Scott (eds) Bacterial Biofilms and their Control in Medicine and Industry. British Biofilms Club, BioLine, Cardiff, pp 141-149

Palmgren R, Nielsen P H (1996) Accumulation of DNA in the exopolymer matrix of activated sludge and bacterial cultures. Water Sci Technol 34: 233-240

Pereira M O, Vieira M J (2001) Effects of the interactions between glutaraldehyde and the polymeric matrix on the efficacy of the biocide against Pseudomonas fluorescens biofilms. Biofouling 17: 93-101

Pereira M O, Vieira M J, Melo L F (2002) The role of kaolin particles in the performance of a carbamate based-biocide for water bacterial control. Water Environ Res 74: 235-241

Pereira M O, Vieira M J, Beleza V M, Melo L F (1998) Retention of bacteria in cellulose fibres as a means of reducing biofouling in paper pulp production processes. Biofouling 13: 1-18

Russel A D (1995) Mechanisms of bacterial resistance to biocides. Int Biodeterior Biodegr 36: 247-265

Simons C, Walsh S E, Maillard J-Y, Russel A D (2000) A note: Ortho-phthalaldehyde: proposed mechanism of action of a new antimicrobial agent. Lett Appl Microbiol 31: 299-302

Stelmack P L, Gray M R, Pickard M A (1999) Bacterial adhesion to soil contaminants in the presence of surfactants. Appl Environ Microbiol 65: 163-168

Walsh S E, Maillard J-Y, Russel A D (1999a) Ortho-phthalaldehyde: a possible alternative to glutaraldehyde for high level disinfection. I Appl Microbiol 86: 1039-1046

Walsh S E, Maillard J-Y, Simons C, Russel A D (1999b) Studies on the mechanisms of the antimicrobial action of ortho-phthaldehyde. J Appl Microbiol 87: 702-710

Walsh S E, Maillard J-Y, Russel A D, Hann A C (2001) Possible mechanisms for the relative efficacies of ortho-phthalaldehyde and glutaraldehyde against glutaraldehyde-resistant Mycobacterium chelonae. J Appl Microbiol 91: 80-92

Workman W E, Day D F (1984) Enzymatic hydrolysis of inulin to fructose by glutaraldehyde fixed yeast cells. Biotechnol Bioeng 26: $905-910$ 